\title{
Socio Economic Aspects of the Fishers Engaged in Hilsa Fisheries in Hooghly Estuary of West Bengal, India
}

\author{
Ashim Kumar Nath ${ }^{1}$, Bidita Banerjee ${ }^{1} \&$ Samik Ray $^{2}$ \\ ${ }^{1}$ Aquatic Ecology and Fisheries Laboratory Department of Zoology Sidho-Kanho-Birsha University \\ Purulia, West Bengal, India \\ ${ }^{2}$ Department of Economics Serampore College Serampore, Hooghly, West Bengal, India \\ nathasim@yahoo.com
}

\begin{abstract}
In India it is important to analyze socio-economic and cultural status of the fishermen for the development and long run sustainability of aquaculture. The fishers are the backbone of this large fishing oriented business and only they can play the most important role for the conservation and development of Fishery. A large no. of fishers engaged in fishing activities in the States of Gangetic plain. Among them highest number of fishermen are from West Bengal (28.71\%). An important fish Hilsa (Tenualosa ilisha), on the other hand accounts for 15-20\% of the total fish landing of Hooghly estuary and a large number of fishermen are associated with hilsa fish catch. Studied area includes three upstream stations (Tribeny, Barrackpore and Ariadaha) and one downstream (Kakdwip) station in Hooghly estuarine system of West Bengal. Study was conducted from March, 2010 to February, 2012 by taking responses from the fishermen on different socioeconomic aspects of their day to day living. In most cases it was found that the Government rules are violated. Mesh size is found below $90 \mathrm{~mm}$ range. The juveniles are randomly caught because of their wretched socioeconomic structure.
\end{abstract}

Present study reveals most of the fishermen have kaccha mud built houses. In most of the cases they have either illegal connections or no electricity. Education and health aspects are neglected. In lower stretch the scenario is better to some extent as fishers are having alternative job options. Most of the fishermen used to depend upon hilsa catch as this is a highly profitable business and they are in this profession generation after generation. In downstream they do it in an orderly manner still the grass root level fishermen are facing many problems. They are paid Rs. 1000 in a trip and also a small amount of profit percentage. The boat owners have very large maintenance cost.

During last few decades' hilsa catch has depleted in the Hooghly stretches. Moreover, the fish catch is passing through many marketing channels. Thus though the fish is sold at market about Rs. 1000 per kg, the fishermen get a small amount of that in both up and downstream.

Keywords: Hilsa, Hooghly Estuary, Socio-Economic Condition, CPUE

\section{INTRODUCTION}

Hilsa is a highly delicious fish food with heavy market demands. The fish is found along the long stretches of Hooghly estuarine system. It is mainly a marine fish which come to riverine water for spawning (De and Saigal, 1989). In today's world marine resources are immensely exploited. Overexploitation diminishes species population as well as economic return. As the most valuable species are over fished they are quickly replaced by catches of less desirable ones which is called 'fishing down the value chain'. A large group of people are associated with hilsa fishing since long due to high economic value of the fish. This fish is a highly nutritive fish with affordable prices. It is observed that life of fishermen entangled with poverty as fishers are 'poorest of the poor' (Bailey et al., 1986) particularly in third world countries. These people are backbone of this fishery oriented business. Most of these fishermen are from 'Malo' community, the word come from Arabic 'Mallaha' (Azad and Haque, 2003). According to Das and Samanta (2010) $28.71 \%$ of the Gangetic plain fishermen are from West Bengal. About, 15-20\% of the total fish landings of the Hooghly estuary are hilsa (Mohanty et. al., 2011). Environmentally sustainable use of fish resources is central to the fisheries management and is dependent on the fishers who exploit these resources. Though there are many reasons for hilsa catch decline- overexploitation is a major cause particularly catches of 
juveniles and brooder hilsa. Thus in depth study on the socio-economic aspects of hilsa fishers is essential for management of hilsa fishery in Hooghly estuary.

The fish activity increases in monsoonal time also a second small peak in fish catch was found in earlier reports (Hora, 1938; Pillay, 1958). Now a day's hilsa catch is declining and the present study will highlight the socio-economic conditions of Hilsa fisher's in Hooghly-estuarine region.

\section{Materials AND Methods}

Along a $126 \mathrm{~km}$ stretch of river Hooghly four stations are selected. One station is selected at Kakdwip (Station 1: South 24 Parganas; $21^{\circ} 52 \mathrm{~N}, 88^{\circ} 11^{\mathrm{E}} \mathrm{E}$ ) and rest three sites are along the upstream of Hooghly estuarine region viz. Ariadaha (Station 2: District Kolkata $22^{\circ} 39^{\prime} \mathrm{N}, 88^{\circ} 21^{\top} \mathrm{E}$ ), Barrack pore (Station 3: District North 24 Parganas, $22^{\circ} 46$ N, 88 20 E) and Tribeny (Station 4: District Hooghly, $22^{\circ} 59 \mathrm{~N}, 88^{\circ} 23^{\mathrm{K}} \mathrm{E}$ ) depending on the availability of the fishermen and these stations are famous for hilsa catches. Fishers were randomly selected.

The study is based on a survey from March, 2010 to February 2012. Semi structured and structured interview schedule was used during the survey. Total 100 fishers were interviewed personally in four stations. The number of fishers engaged in hilsa fishing in the studied upstream stations is very less than down stream. The sample size tallies with the work of Ahsan et. al. (2014). Fortnightly hilsa catch data are taken from the fishermen during high tide mainly. The catch data are analyzed following the standard methods (Jhingran et. al., 1969). The regular fishers of river Hooghly differ from the hilsa fishers. The nets and boats use in this aspect are exclusively for catching hilsa. According to current market price the fishers' economic conditions are studied. Data on labor requirements for each craft gear combination in fishing, employment in the processing, and subsidiary activities are collected from the sample centers. A datasheet was prepared for this aspect and the following information are sought from the fishermen during the survey (Tyagi, 2009; Basak, 2010). The relevant questions are

1. Whether the person concerned interviewed is a full timer or part timer hilsa fishermen

2. The amount of investment if any

3. Caste

4. No. of family member

5. No. of children

6. Whether own house or not and present housing condition

7. Facility of electricity present or not at the fishermen's residence

8. Education level

9. Health condition

10. No. of assets (like TV, mobile, cycle etc) possessed

11. Whether the person concerned has alternative income source or not; if yes then what is that

12. Income from other source

13. Family expenditure

14. Cooperative, lending society if present.

\section{RESULTS AND DISCUSSION}

\subsection{In Upstream}

Present study reveals the winter catch has increased compared to the monsoonal fish catch (Table 1 and Fig.1).

Table1. Mean catch and Income data in upstream centers

\begin{tabular}{|c|c|c|c|c|}
\hline Year & \multicolumn{2}{|c|}{ Monsoon } & \multicolumn{2}{c|}{ Other time } \\
\hline & Catch $(\mathrm{Kg})$ & Income (Rs.)/ fisherman & Catch $(\mathrm{Kg})$ & Income (Rs.)/ fisherman \\
\hline $2010-11$ & 0.66 & 128.60 & 0.8 & 146.40 \\
\hline $2011-12$ & 0.53 & 99 & 1.2 & 231.20 \\
\hline
\end{tabular}




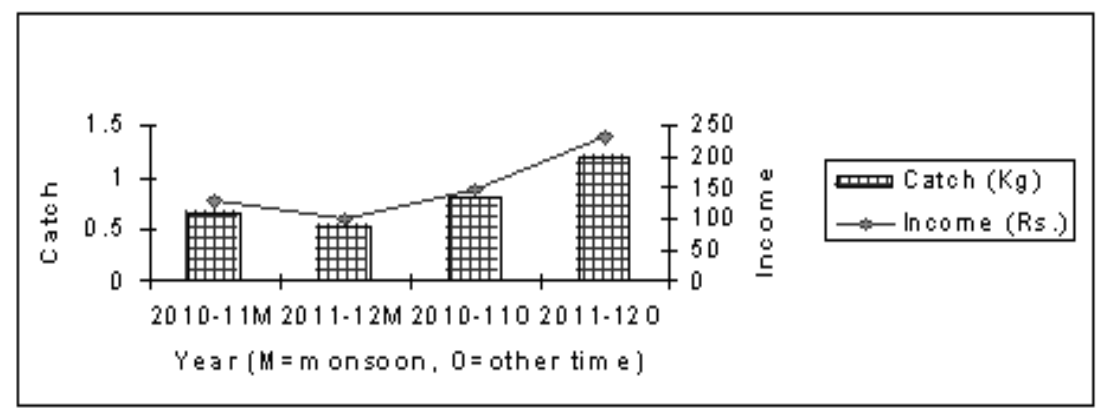

Fig1. Hilsa Fisher's income per effort in Upstream

It was found that monsoon catch has decreased compared to the previous catch which is a major reason of economic distress of the fishermen in Hooghly estuary. Actually, the twin problem of destruction of the eggs of hilsa by the use of small mesh sized net during its catch and high rate of juvenile fish catch have put the lives of both the hilsa fish and fishermen in deep trouble.

The fishermen use small manually driven boats accommodating 2 to 3 persons. The boats are either made by them or bought usually from Balagarh, Hooghly. Recently buying trend has increased and Balagar, a place in Hooghly district of West Bengal is preferred. The cost to make such a boat varies from Rs. 20,000 to 30,000. The nets being used in this respect is gill net locally named as 'current jal'. Formerly women of the families assist to make this net but now all are machine made net. It costs Rs. 800-1200 per kg as the quality varies. Very few fishermen operate Shangla jaal (clap trap) for hilsa fishing particularly in Barrackpore area of Hooghly estuary.

Generally boat owners get the higher percentage of the profit. As the expenditure is one time and the work is labor based the total income is their profit. The owners get 50 to $60 \%$ of the profit. The rest is divided among the other fishermen. The fishes come to the market after moving through various channels from the fisher to the whole seller or a commission agent or retailer or local dealer etc. and ultimately to the consumer.

Fish which is available at the rate of Rs. 600 to 1000 per $\mathrm{kg}$ in the market is sold by the fishers to the sellers in Rs. 200-600 per kg according to the size and season. The highest demand is on the MayJune and in February. The income of the fishers from one boat effort is varied from Nil to Rs. 600 during the survey (Table 2).

Table2. Range of catch and income data in upstream centers

\begin{tabular}{|c|c|c|c|c|c|c|c|}
\hline \multicolumn{4}{|c|}{$2010-11$} & \multicolumn{4}{c|}{$2011-12$} \\
\hline \multicolumn{2}{|c|}{ Monsoon time } & \multicolumn{2}{c|}{ Other time } & \multicolumn{2}{c|}{ Monsoon time } & \multicolumn{2}{c|}{ Other time } \\
\hline $\begin{array}{c}\text { Catch } \\
(\mathrm{kg})\end{array}$ & $\begin{array}{c}\text { Income } \\
(\mathrm{Rs} .)\end{array}$ & $\begin{array}{c}\text { Catch } \\
(\mathrm{kg})\end{array}$ & $\begin{array}{c}\text { Income } \\
(\text { Rs. })\end{array}$ & $\begin{array}{c}\text { Catch } \\
(\mathrm{kg})\end{array}$ & $\begin{array}{c}\text { Income } \\
(\text { Rs. })\end{array}$ & $\begin{array}{c}\text { Catch } \\
(\mathrm{kg})\end{array}$ & $\begin{array}{c}\text { Income } \\
(\mathrm{Rs} .)\end{array}$ \\
\hline $0-1.8$ & $0-432$ & $0-1.8$ & $0-600$ & $0-1.8$ & $0-432$ & $0-2$ & $0-600$ \\
\hline
\end{tabular}

It is important to note that if all the members of the boat are from the same family and higher fish catch occurred and market price is better then only such income is possible. Thus, the income is a matter of various chance factors. During this study period, it was found that the exact income varies between Rs. 99 to 231/- in a day during this study period (Table 1). Bhaumik and Sharma (2012) reported that income of fishers per month varies between Rs. 3000 and Rs. 6000 in the upstream and catch on an average is 1 to $5 \mathrm{~kg} / \mathrm{boat} /$ day throughout the year.

Many of the fishermen have to get shifted to other part time professions due to less and uncertain income. During the study $78.18 \%$ of the fishers are found as full time hilsa fishers. Fishermen with own specialized nets and boats for hilsa catching are counted as full timer. Most of them have their own nets and boats. They are in this profession from many years. Some are for more than six decades in this profession. Around, $21.82 \%$ of the fishers are part timer. Among the full timer hilsa fishers $16.36 \%$ of people are solely dependent upon hilsa catch and has no other options. $74.55 \%$ of the hilsa fishers have some alternative job options but all are day based labor and are highly uncertain like masonry, other fish selling, etc. It is found that only $9.09 \%$ people have fixed alternative job options (Table 3). 
Ashim Kumar Nath et al.

Table3. Various social features of the upstream hilsa fishermen

\begin{tabular}{|l|l|l|}
\hline Features & General & Percentage \\
\cline { 2 - 3 } Caste & SC & 9.0 \\
\hline \multirow{5}{*}{ Education } & $4^{\text {th }}$ class & 90.91 \\
\cline { 2 - 3 } & $8^{\text {th }}$ standard & 29.09 \\
\cline { 2 - 3 } & $10^{\text {th }}$ plus & 67.27 \\
\hline Kaccha House & Poor conditioned house & 3.64 \\
\cline { 2 - 3 } & better conditioned house & 76.35 \\
\hline \multirow{3}{*}{ Farming options } & Only hilsa fishing & 23.64 \\
\cline { 2 - 3 } & Strong alternate earning option & 16.36 \\
\cline { 2 - 3 } & no such strong option & 9.09 \\
\hline Monthly expense & Range & 74.55 \\
\cline { 2 - 3 } & Mean & Rs.2500-8000 \\
\hline
\end{tabular}

The study shows a shifting in the profession is occurring. The 'Push and Pull' effect due to low income from hilsa catch is pressurizing the fishers to shift their occupation though the hilsa fishing is their most comfortable zone. The age group of these people is above forty years in more than half of the cases $(65 \%)$. New generations are not interested in this uncertain profession. The present generation fishermen have provided formal education to their wards as much as possible for choosing occupation other than fishing. But the next generation people being forced by circumstances i.e. due to the absence of alternative job opportunities act as part-time fishermen to assist the experienced ones.

Such uncertainty led this people to catch juvenile and young hilsa randomly whenever found. In the year 2010-11, 10g to 200g sized hilsa fishes were available in this stretch randomly. The fishers use small mesh sized nets to catch this fish. Most are traditional fishers. Lending is a usual part of their lives and they generally prefer personal loans. Few lending societies ('Bandhan, cooperative society etc.) are also found who provide money named as 'Dadon' for the business. No efficient and smoothly functioning cooperative societies of the fishermen are found in the context of hilsa fishing. Since the fishermen are not in the habit of saving and in most of the cases income is not sufficient to cover day to day expenses and for repayment of loan, they are forced to take further loans during lean season. A number of household ancillary industries such as net making and repairing, making of baskets, coir products, processing, preparation of value added products have very good scope for providing employment of these fishermen throughout the year. Way to save the condition of the fishers is to formulate credit facilities through institutional financing with appropriate terms and conditions and the most suitable organization for this purpose is the cooperative society of the fishermen. Success of the cooperative is possible with full involvement of ordinary fishermen.

Their social study reveals most of the people have 'kaccha houses' though the standard varies. About $10.91 \%$ people's condition is very poor with one room houses. It is observed that $65.44 \%$ fishers have houses which have fencing, tally covering on roof top and minimum two rooms with inadequate toilet facilities. Some of the fishermen (23.64\%) have brick built houses but the constructions are not good enough. Some of them are deprived of the facility of electricity at their residence. It is well known that cycle, television and mobile phones are three important assets for maintaining their livelihood. The survey brings out that $14.55 \%$ people do not have television. The educational background of the fisher is not impressive because $29.09 \%$ of the fishermen have primary school education (fourth standard). Eight to ten standard student percentages is $67.27 \%$ and higher educated people level is $3.64 \%$. The social aspects are denoted by the graphs (Fig. 2 to 5 ).

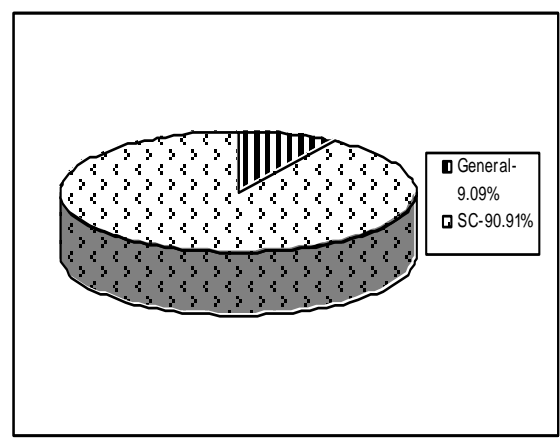

Fig2. General and SC category fishermen in the upstream 


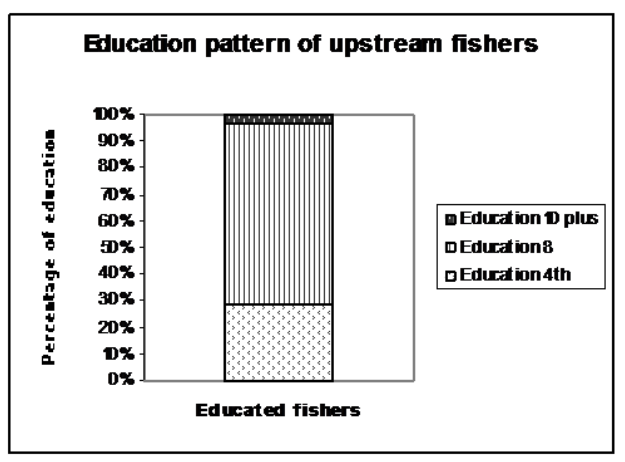

Fig3. Educational condition upstream fishermen

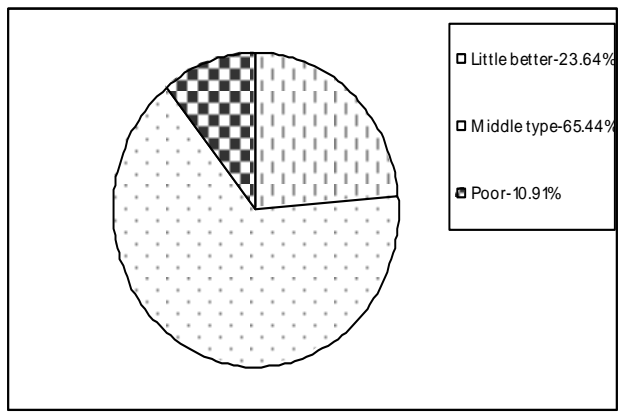

Fig4. Housing condition of upstream fishermen

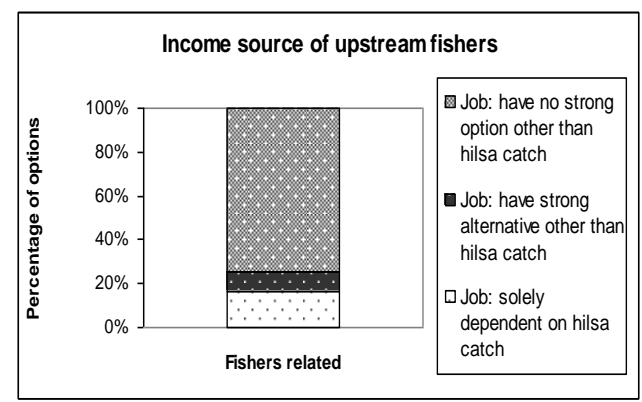

Fig5. Job alternative option of upstream hilsa fishers

The expense per family ranges between Rs. 2500-8000. The mean expense is Rs. 4590.91 (Table 3).

\subsection{In Downstream}

In Kakdwip region the whole scenario is different from the upstream. Here two groups are found both are socially different but dependent upon each other, one is owner group of people and the other is labor group of people. The labor group of people is mainly from backward regions of South 24 Parganas and they are not proper resident of Kakdwip. They are either illiterate or $4^{\text {th }}$ standard educated. They live in wretched conditioned muddy houses. In Kakdwip subdivision total no. of trawler is about 2000. In West Bengal 9000 trawlers (both mechanized and non mechanized) operate during the season. A vast group of people are related to this profession as labors. A ban in hilsa fishing sustains from $15^{\text {th }}$ April to $15^{\text {th }}$ June in this region (Ahsan et. al., 2014). In downstream, fishers catch hilsa in groups by hiring mechanized boats which are locally known as trawlers. Trawlers are fitted with 4-6 cylinder engines. Some trawlers are fitted with 1-2 cylinder engines. Such mechanized trawlers generally catch fish in the marine zones of the estuary i.e. $30 \mathrm{~km}$ from the estuarine mouth during monsoon months whereas they go up to $60 \mathrm{~km}$ during winter season. Each trawler accommodates 8-11 fishers.

Owners are the investors who invest Rupees 1.2 to 1.5 lakhs per trip. The trawlers used are all mechanized and as the costing of it is one time it is not included in the expense. The expense includes fuel costing, labor payment, food arrangement in boat and cold storage etc. Fuel cost per barrel is about Rupees ten thousand. During this study it is seen only in the monsoon time the owners have good income (Table 4) but other time they are running in a loss. 
Ashim Kumar Nath et al.

Table4. Catch and Income of the owners and labors per trawler trip

\begin{tabular}{|c|c|c|c|c|c|}
\hline \multicolumn{5}{|c|}{ Year 2010-11 } \\
\hline Catch per trawler (Kg) & Owner's Income (Rs.) (60\% of the Total earning) & \multicolumn{2}{c|}{ Labor's Income ( Rs.) } \\
\hline Monsoon & Other time & Monsoon & Other time & Monsoon & Other time \\
\hline 400 & $0-200$ & 24000 & 3000 & 1800 & 1000 \\
\hline \multicolumn{7}{|c|}{ Year 2011-12 } \\
\hline Catch per trawler (Kg) & Owner's Income in Rs. (60\% of the Total earning) & \multicolumn{2}{c|}{ Labor's Income ( Rs.) } \\
\hline Monsoon & Other time & Monsoon & Other time & Monsoon & Other time \\
\hline 450 & $0-150$ & 60000 & 5000 & 2200 & 1000 \\
\hline
\end{tabular}

Moreover the income in monsoon period is not also so good when compared to the investment. Pricing of the fish occur primarily through auctioning in the market around downstream. The labors are paid Rs. 1000 per trip and also a small profit percentage is given. The amount varies from Rs. 1800 to 2200 per trip provided good profit has occurred (Table 4). In the off season fishers do net repairing josb in per day payment basis. They are very little educated (only $4^{\text {th }}$ standard in most cases) and social study on them shows they have kaccha houses with minimum facilities. But the trawler owner personalities are well educated in most of the cases and they help those poor people whenever needed. A good relationship is observed between these two categories which is very healthy. A large group of labors (about 15\%) are now - a - days shifting to either Mumbai for hook line oriented job or to Kerala for masonry jobs. Here they income Rs. 300-350 per day. Use of small mesh sized nets is found to catch below $500 \mathrm{~g}$ weighed hilsa. A smaller mesh sized nets are highly used here in downstream to collect 'meen' or prawn seeds which causes destruction of other seeds. Since last five years the condition is turning to worst so the business is running in loss.

\section{Conclusion}

Last decades hilsa has immensely exploited. The total catch data shows what amount of fishes was caught by fishers in this selected zone during this survey time (Table 5).

Table5. Total catch in selected stations of Up and Down stream

\begin{tabular}{|c|c|c|}
\hline Years & Upstream (station 2,3,4) total catch Ton) & Downstream (station1)total Catch (Ton) \\
\hline March 2010-Feb. 2011 & 0.884 & 4800 \\
\hline March 2011-Feb. 2012 & 0.585 & 6800 \\
\hline
\end{tabular}

Over exploitation caused by crowding of regular as well as part time fishermen in the hope of increased sales and profit in a particular fish catch station reduces the quantity along with variety of fish stock. This in turn adversely affects the fishery in terms of loss of bio diversity as well as decrease in income. The scenario is needed to be changed. A highly conscious prohibition is needed in this respect. In that case strong Government effort and alternative job options are highly needed. Hilsa is a resource of our country. Not only is it a highly economically profitable fish, it is also related to our social, cultural aspects.

It is our responsibility to make sure the proper use of these valuable resources. But, it is not possible only through promulgation of laws, effort is needed for the betterment of the socio-economic condition of the people who are engaged in fishing. Government effort is very much essential in this respect. But no such strong effort has noticed during this period. Even the people who gamble their lives for supplying us this delicious fish food staying in the sea they are not even informed about bad weather condition time to time.

For development of fishery in India the condition of the fishermen should be improved. Due to seasonal nature of the fishery, major portion of the annual income of a fisherman household is earned within a period of five to six months. This situation affects the living condition of the fisher folk. The poverty of the artisanal fishermen is mainly attributed to this seasonality. Now-a-day's catch also decreased. In the absence of any good alternative employment opportunity, the artisanal fishermen have to depend on money lenders or fish traders to tide over this lean season which ultimately keeps them under perpetual indebtedness and consequently under poverty. They are in a severe - condition without any ambition, social consciousness. Socio-economic development of the fishers is intimately connected with the development of Indian fishery. Financial inclusion, telephone facilities for quick 
contact, regular meetings, lab to land programs, audio visual demonstrations by Fisheries extension officers, participation of Non-Government Organization (NGO) are very much beneficial in this respect. There are many facilities which are provided by the Government but most of the time they are fully unaware about these efforts (Kumar et. al. 2003). Education and primary health development is important in this respect. For implementation of laws and rules both methodological and practical aspects have to be considered.

\section{ACKNOWLEDGEMENTS}

Authors are grateful to UGC for providing fund in Major Research Project (UGC FNo.38 - 198/2009 (SR) and to the Principal, Serampore College for giving permission to do the work. Thanks are due to Dr. M.V. Gupta, World Food Prize Laureate, Former ADG, World Fish Centre, Prof. Mohan Joseph Modayil, Member (Retd.) ASRB, Dr. V.V.Sugunan, ADG (ICAR) (Retd.), Dr. J.K.Jena, DDG (Fy), ICAR, Dr. D.K.De, Principal Scientist (Retd.), CIFRI, Mrs. G. K. Vinchi, Principal Scientist (Retd.), CIFRI and Prof. Samir Banerjee, University of Calcutta for inspiring us to do the work.

\section{REFERENCES}

[1] Ahsan, D. A., Naser, M. N K., Bhaumik, U., Hazra, S. and Bhattacharya, S. B. (2014). Migration, Spawning patterns and conservation of Hilsa shad (Tenualosa ilisha) in Bangladesh and India. Ecosystems for life: A Bangladesh - India initiative - Dialogue for sustainable management of trans-boundary water regimes in South-Asia. Academic Foundation, New Delhi in association with $I U C N$. Total pages 95 .

[2] Azad, M. A. K. and Haque, M. M. (2003). Issued related to livelihood condition of coastal fishers in Bangladesh with special relation to Integrated Coastal Zone Management. J. Animal and Veterinary advance 2(10): 564-571.

[3] Bailey, C., Cycon, D. and Morris, M. (1986). Fisheries development in the Third World: the role of International agencies. World Development 14: 1269-1275.

[4] Basak, R. (2010). Information needs and information seeking behaviour of research workers in the field of fishery and fish farmers in West Bengal. PhD Thesis. Jadavpur University.

[5] Bhaumik, U and Sharma, A.P. (2012). Present status of Hilsa in Hooghly-Bhagirathi river. CIFRI, Bulletin No. 179.

[6] Das, M. K. and Samanta, S. (2010). Improve aquatic habitat- save fish and fisheries resource and environment management division. CIFRI Bulletin No. 166:

[7] De, D. K. and Saigal, B. N. (1989). Spawning of the Tenualosa ilisha (Ham.) in the Hooghly estuary. J.Inland Fish. Soc. India, 21(2): 46-48.

[8] Hora, S. L. (1938). A preliminary note on the spawning grounds and bionomics of the so called Indian shad, Hilsa ilisha (Ham.) in the river Ganges. Rec.Indian Mus., Calcutta, 40(2): 147-148.

[9] Jhingran, V. G., Natarajan, A. V., Banerjee, S. M. and David, A. (1969). Methodology on reservoir fisheries investigations in India. CIFRI Bulletin No.12..

[10] Kathia, P. K., Vass, K. K., Sharma, A. P., Bhaumik, U. and Chandra. G. (2010). Issues and tools for social sciences research in inland fisheries. CIFRI Bulletin No. 163.

[11] Kumar, A., Katiha, P. K., Joshi P. K. (2003). A profile of peoples, technologies and policies in fisheries sectors in India. National Centre for Agricultural Economics and Policy Research

[12] New Delhi, India. Total pages 159.

[13] Mohanty, B. P., Das, S., Bhowmik U., Sharma, A. P. (2011). Tenualosa ilisha, A rich source of $\omega_{3}$ fatty acids. CIFRI Bull. No. 171.

[14] Pillay, T. V. R. (1958). Biology of the Hilsa of the river Hooghly. Indian J. Fish., 5(2): 201-257.

[15] Tyagi, R. K. (2009). Socioeconomic status of fisheries of river Ganga. CIFRI Bull. No. 160. 